\title{
Collaborative Care in Primary Health Care Focus on Management of Depression
}

\author{
Yunatan Iko Wicaksono, M.D. ${ }^{1}$, Nining Febriyana, M.D. ${ }^{2}$
}

${ }^{1}$ Department of Psychiatry, Faculty of Medicine, Universitas Airlangga, Surabaya, Indonesia - Dr. Soetomo General Hospital Surabaya, Indonesia.

2Division of Child and Adolescence, Department of Psychiatry, Faculty of Medicine, Universitas Airlangga, Surabaya, IndonesiaDr. Soetomo General Hospital Surabaya, Indonesia.

Received 22 October 2021 • Revised 11 December 2021 • Accepted 13 January 2022 • Published online 23 February 2022

\begin{abstract}
:
Depression often goes undetected and undertreated in primary care settings. Collaborative management of mental disorders; such as depression, with the involvement of a multidisciplinary team in primary care, is an effective solution to improve depression treatment. This study aimed to understand collaborative care for depression management in primary health care. This was in order to evaluate contemporary conceptions of Collaborative Care (CC) for primary medical problems. This study examined numerous studies from the Pubmed Central International database; including, a textbook, a review paper, a commentary, and an editorial. The CC approach has five fundamental elements: patient-centered team care, population-based care, target measurement-based therapy, evidence-based care, and accountable care. The CC approach uses a "patient education manager," to involve patient care decision-makers, monitor results, conduct follow-ups, support the management of primary care physician antidepressant therapies, and coordinate services from numerous providers. The conclusion from this review is that CC is a holistic, multidisciplinary, and proactive treatment model to manage depression. Effective treatment of depression utilizing a CC model could therefore have major benefits; including, better clinical improvement, improved patient quality of life, and cost-effectiveness.
\end{abstract}

Keywords: collaboration, health services, medical care, mental disease, primary care

Contact: Nining Febriyana, M.D.

Division of Child and Adolescence, Department of Psychiatry, Faculty of Medicine,

Universitas Airlangga, Surabaya, Indonesia - Dr. Soetomo General Hospital Surabaya,

Mayjen Prof. Dr. Moestopo 47, Surabaya, East Java, 60131, Indonesia.

E-mail: dr_niningf@yahoo.com

(c) 2022 JHSMR. Hosting by Prince of Songkla University. All rights reserved.

This is an open access article under the CC BY-NC-ND license

(http://www.jhsmr.org/index.php/jhsmr/about/editorialPolicies\#openAccessPolicy).
J Health Sci Med Res 2022;40(6):705-715 doi: 10.31584/jhsmr.2022866 www.jhsmr.org 


\section{Introduction}

Mental illnesses are common in primary health care; especially depressive ones. However, they are not always recognized nor properly treated. ${ }^{1,2}$ Depression is a major health concern, and is predicted to be the second-largest cause of global disability by 2020 . Moreover, depression is the most significant health condition. Yet, in the management and treatment of many illnesses, health systems often function passively. This is partly due to the lack of detection and under-treatment of depression in primary care. In addition, research has indicated that doctors in primary care do not recognise 30.0 to $50.0 \%$ of depressive people.,

Many primary care doctors believe that the management of physical sickness is their primary obligation, With most having no awareness of mental illnesses; which are usually deemed outside of the scope of their services. Furthermore, interviews and emotional problems typically take longer, contrasting to the current state of affairs, when efficiency tests and cost reductions are conducted quickly. Therefore, primary care physicians are often unable to offer all required care during an outpatient appointment within a limited period. The need to support primary care doctors in treating depression utilizing a collaborative approach is therefore an acceptable strategy. ${ }^{1,2}$

Collaborative care (CC) is a systematic way for people with chronic diseases to manage therapy and medicines. ${ }^{4,5}$ $\mathrm{CC}$ is a complicated strategy that tries to foster intimate working connections among members of the caring team, in order to provide high-quality care to patients in addition to improving both mental and physical health outcomes. ${ }^{6,7}$ CC incorporates more than one health care worker, working together to increase communication and collaboration, via the division of labor principle. ${ }^{7,8}$ Collaborative mental health care; such as depression, is an effective way to increase depression treatment, with the engagement of multidisciplinary teams in primary care. Substantial evidence has suggested that collaborative therapy is twice as effective and economical for patients with depression in more than 80 randomized controlled studies (RCTs). ${ }^{4,9,10}$ Therefore, the purpose of this review is to understand in detail collaborative care as depression management in primary health care; as in to how it is implemented, in addition to the barriers of its implementation.

\section{Material and Methods}

Employed literature was obtained from online search engines; such as, the PubMed Central International database, Science Direct, Google Scholar, including a textbook, a review paper, a commentary, and an editorial, the World Health Organization (WHO) website, and the Ministry of Health of the Republic of Indonesia. The keywords were: collaborative care or collaboration care, primary health care or primary care, management or treatment or therapy, and depression or mental health. Finally, we obtained 38 English and Indonesian literatures, with a level of evidence of $1 \mathrm{~A}-2 \mathrm{C}$. The level of evidence was determined based on the Oxford Center for Evidencebased Medicine Level of Evidence classification. ${ }^{11}$

\section{The concept of collaborative care}

$\mathrm{CC}$ is an involvement in therapy for people with chronic diseases; such as, depression, diabetes and cardiovascular disease, within primary care settings, utilizing a systematic technique for treatment and medication. Collaborative care is a complex intervention; consisting of several active components, and requiring the enrolment of various professional actors from different sectors. It strives primarily to build a firmer working relationship between primary and specialty health care members (family doctors or practitioners and nurses). The CC teams are integrated into primary care to improve the quality of care and outcomes of illnesses. CC supports four main components: a multi- 
professional approach to patient therapy, a structured management plan tailored to the needs of patients, proactive follow ups, evidence-based treatments, and processes for improving inter-professional communication; such as, routines and regular team meetings or joint records. ${ }^{4-8}$

The CC paradigm includes five fundamental elements: caring for patients, population-based therapy, measurement-based treatment, evidentiary treatment, and responsible care. ${ }^{5}$ There are 6 important components in $\mathrm{CC}$ that assist the programs to operate appropriately. These are summarized in Table 1. Each component has its own role and task, and they all work together to increase communication by implementing the divisions of the labor paradigm. The overall purpose of this collaboration is to provide patients with high-quality care, while also improving mental and physical health outcomes. ${ }^{6,7,12}$ Unlike the general approach model, the collaborative care model uses patient training, involvement in treatment decisions, monitoring outcomes, monitoring, the management of primary care provider (PCP) antidepressant treatment, and the coordination of multi-provider services (such as, consultation with a psychiatrist and referral if clinically indicated). ${ }^{13}$

\section{Collaborative care for depression manage- ment in primary health care}

The prevalence of depression cases in primary

\section{health care}

Depression is a mood disorder that is quite frequently encountered, and approximately $3.0-5.0 \%$ of the population will experience depression at some point in their lives. It may described as: feelings of sadness, loss, or irritability. In addition, a depressed individual will tend to experience cognitive distortions; such as, self-criticism, guilt, feelings of worthlessness, low self-confidence, pessimism, and hopelessness. Furthermore, there is a feeling of laziness, a lack of energy, psychomotor retardation, and the withdrawal from social relationships. ${ }^{14,15}$

Primary health care $(\mathrm{PHC})$ is a basic health care service, based on methods, sciences, and technologies. Additionally, due to their entire participation and affordable costs for the communities and the State, they are acceptable to both individuals and families in the community in maintaining all development levels in a spirit of selfconfidence and self-determination. ${ }^{13,16}$

The prevailing rate of depression was $10.4 \%$, based on International Statistical Classification of Disease and Related Health Problem or ICD 10, research carried out by $\mathrm{WHO}$ in $\mathrm{PHC}$, which comprisedof 26,000 patients in 15 health centers globally. ${ }^{17}$ The Republic of Indonesia Health Ministry Data shows that for people aged 15 years and older, the prevalence of depressive disorders is about $6.2 \%$. The annual prevalence for major depressive disorder ranges from 5.0 to $13.0 \%$ for adults in primary care clinical settings and $6.0-9.0 \%$ for older people. ${ }^{18}$ Adults have a lower prevalence of depression than teenagers. The intensity; however, was greater in adults, who were at the highest risk of suicide. Up to $50.0-70.0 \%$ of people having committed suicide had seen a primary care physician during the previous month, and $39.0 \%$ had seen a physician within one week of their death. ${ }^{19}$ Less than $15.0 \%$ of patients receive adequate treatment to achieve remission with an accurate diagnosis of depression, whom had access to primary care. By sending patients to specialized mental health facilities, PCP continues to face barriers. Furthermore, doctors, doctor assistants, and nurses often have to deal with time or inadequate training to deal with mental health issues effectively. ${ }^{20}$ 
Table 1 Collaborative care components along with detailed job descriptions ${ }^{1}$

\begin{tabular}{|c|c|c|}
\hline No. & Component & Job Description \\
\hline 1. & Patient & $\begin{array}{l}\text { a. The most important person in the CC team. } \\
\text { b. Works with the PCP and the Behavioral Health Provider (BHP)/Care Manager (CM). } \\
\text { c. Health, symptoms, and working changes report. } \\
\text { d. Set objectives for team treatment. } \\
\text { e. Monitor the clinical progress of the outcome measures reported by the patient. } \\
\text { f. Asks and addresses care problems. } \\
\text { g. Understands therapeutic plans; including, behavioral treatments objectives and drug names/ } \\
\text { doses. }\end{array}$ \\
\hline 2. & Primary Care Provider (PCP) & $\begin{array}{l}\text { a. Practitioners general. } \\
\text { b. Monitor all elements of the treatment of the patient. } \\
\text { c. Presents a "warm handoff" CC Team. } \\
\text { d. Common psychiatric diagnoses. } \\
\text { e. Recommends psychiatric medicines as necessary. } \\
\text { f. Therapeutic adjustments in cooperation with BHP/CM, psychiatric consultants, and others. }\end{array}$ \\
\hline 3. & $\begin{array}{l}\text { Behavioral Health Provider } \\
\text { (BHP) }\end{array}$ & $\begin{array}{l}\text { a. Pflege workers, clinicians, or those with special mental health know-how. } \\
\text { b. Works with PCP closely and assists in managing primary care patient case-load. } \\
\text { c. Encourages the involvement and training of patients. } \\
\text { d. Conducts initial structured assessments and follow-ups. } \\
\text { e. Tracks therapy responses, systematically through behavioral health actions. } \\
\text { f. Provides or refers to other BHPs, for these services for short, evidence-based behavioral } \\
\text { therapies. } \\
\text { g. Supports PCP drug management; including: } \\
\text {-Patient aid in identifying where drugs can be received. } \\
\text {-Promoting and encouraging adherence to medicines. } \\
\text {-Involves PCP concerns regarding medicinal products or side effects and adjustment plans for } \\
\text { PCP visits. } \\
\text { h. Checks systematic, weekly psychiatric consultant for problematic patients. } \\
\text { i. Enables referrals to other services as necessary (such as, the treatment of substance abuse, } \\
\text { specialized care, and community resources). } \\
\text { j. Prepares the patient for the avoidance of recurrence. }\end{array}$ \\
\hline 4. & Consultant psychiatry (CP) & $\begin{array}{l}\text { a. Psychiatrist. } \\
\text { b. Supports PCPs and BHPs, delivering frequent consultations (several times) on the work-load } \\
\text { of primary care patients as required. } \\
\text { c. Focuses on patients who do not improve, and who need to be treated or strengthened. } \\
\text { d. Available in-person, telemedical, or referral services for individuals who are complex or } \\
\text { consistently unwell. } \\
\text { e. Provides primary care provider and BHP education and training, when applicable. }\end{array}$ \\
\hline 5. & $\begin{array}{l}\text { Other behavioral health } \\
\text { providers }\end{array}$ & $\begin{array}{l}\text { a. Chemical dependency counselors or other licensed health experts may be included. } \\
\text { b. To provide expert advice/psychotherapy, based on evidence (individual or group). } \\
\text { c. Promoting behavioral health therapies; focusing on behavior. } \\
\text { d. Provide advice/treatment on chemical dependence. } \\
\text { e. Facilitate further services of mental health or drug abuse. }\end{array}$ \\
\hline 6. & $\begin{array}{l}\text { Other significant partners } \\
\text { to be part in team building }\end{array}$ & $\begin{array}{l}\text { a. CEO, managers, physicians, clinic managers. } \\
\text { b. Leaders/champions in medical and mental health. } \\
\text { c. Medical assistants and front desk employees. }\end{array}$ \\
\hline
\end{tabular}

$\mathrm{PCP}=$ Primary Care Provider, BHP=Behavioral Health Provider, $\mathrm{CP}=$ Consultant Psychiatry, $\mathrm{CC}=\mathrm{Collaborative}$ Care, $\mathrm{CEO}=\mathrm{Chief}$ Executive Officer, $\mathrm{CM}=$ Care Manager 


\section{Depression management in primary health care}

The United States Preventive Services Task Force, and The National Institute for Health and Care Excellence of the United Kingdom, advises that routine depression screening in primary health care be done to assist accurate diagnose, effective treat and monitoring of depression. ${ }^{21,22}$ In a study of the Indonesian population, in 2021, it was concluded that it was highly crucial to recognize and prevent depression in primary health care at an early stage. ${ }^{23}$

The Beck Depression Inventory, the 20-item Center for Epidemiological Studies Depression Scale (CES-D), the 9-item Patient Health Questionnaire (PHQ-9), the Quick Inventory of Depressive Symptomatology-Self-Records (QIDS-SR), and The Depression, Anxiety, and Stress Scale (DASS-21) are some major instruments used for depression screening. In all surveys' high sensitivity and specificity were demonstrated. ${ }^{2,24,25}$ The most extensively instrument used in primary care is the Patient Health Questionnaire (PHQ). Furthermore, $\mathrm{PHQ}$ is a free tool and is publicly available. A 17 validation study with meta-analysis demonstrated that the PHQ-9 is suitable in various environments, nations, and populations. The PHQ-9 had a sensitivity of $80.0 \%$ and a specificity of $92.0 \%$, in 14 studies with 5,026 participants. ${ }^{3}$

The implementation of collaborative care for depression management in primary health care

Contributions from a whole team will be included for a period of CC implementation. Implementation of CC for depressed patients in primary health care includes; assessment, eliminating differential diagnoses and identifying provisional diagnoses, administering treatment, conducting follow-ups and adjusting treatment to achieve therapy targets as well as completing treatment and preventing recurrence. Each team member has their own role in the implementation of CC (Table 2). Figure 1 shows the interaction between team members. The PCP, CM, and psychiatrist consultants are the respective team members.
Therefore, every activity requires to be accomplished as part of a shared workflow: when, where, and by whom. ${ }^{12}$ Psychiatrists are important members of the CC team. Additionally, psychiatrists play several roles as team members; including, consultants (both direct and indirect), educators, and provide clinical and team leadership. Some of the characteristics of successful psychiatric consultants are being flexible, team-oriented, willing to tolerate distractions and enjoy educating others. ${ }^{26}$

Good implementation of collaborative care on management of depression; especially in primary health care, has several benefits for both the patient and health professional. An RCT study found that one benefit is a rapid reduction in depression scores, as compared to ordinary treatment. ${ }^{27,28} \mathrm{~A}$ further meta-analysis of comorbid, depressed people with multiple chronic medical problems found that intervention with CC lead to primary care patients, with multiple medical conditions, to better depression and quality of life. ${ }^{29}$ Research conducted by Unützer et al. recorded more than 70 randomized controlled trials of collaborative care, which demonstrated that this approach has a better and more cost-effective clinical improvement effect. $^{4,27}$

The barriers of the implementation of collaborative care for depression management in primary health care

In practice, collaborative care has several barriers that may be faced; however, this does not mean that the CC model cannot be implemented. Good barrier management will result in good implementation as well. Some studies that have been carried out may be used as learning materials for more mature preparation. According to Katon and Unutzer, successful implementation of the model will include overcoming hurdles at the organizational level, in clinical practice, and via creative finance to support the adoption of team-based care. Katon and Unutzer also 
Table 2 The implementation process of collaborative care management in depression in primary health care ${ }^{1}$

\begin{tabular}{|c|c|c|c|}
\hline No. & Implementations & Components & Roles \\
\hline \multirow[t]{4}{*}{1.} & \multirow[t]{4}{*}{$\begin{array}{l}\text { Assessment: } \\
\text { Identifies the major complaints } \\
\text { relating to physical, psychological, } \\
\text { functional, and safety problems. }\end{array}$} & Patient & $\begin{array}{l}\text { Participates in symptoms and function evaluation; which includes: } \\
\text { examining and screening tools and offering informed collateral } \\
\text { consent from health care providers or family/friends. Supplies the } \\
\text { necessary information. Questions about security. }\end{array}$ \\
\hline & & PCP & $\begin{array}{l}\text { Identifying probable depressive illnesses is the primary responsibility } \\
\text { and generally uses basic screening; such as PHQ-9. Assess safety } \\
\text { and coordinates security problems with BHP. }\end{array}$ \\
\hline & & $\mathrm{BHP}$ & $\begin{array}{l}\text { Finishes a complete evaluation; looks for information on depression- } \\
\text { related functional impairments; gathers collateral information. Safety } \\
\text { evaluation. }\end{array}$ \\
\hline & & $\mathrm{CP}$ & $\begin{array}{l}\text { In the case of more complex presentations indicators, expands the } \\
\text { psychiatric difference diagnosis and provides BHP options for more } \\
\text { diagnostic information, through evaluation or collateral information. }\end{array}$ \\
\hline \multirow[t]{4}{*}{2.} & \multirow[t]{4}{*}{$\begin{array}{l}\text { Differential diagnosis and tentative } \\
\text { diagnosis identification: } \\
\text { Exclude contributions to health } \\
\text { problems and illnesses associated } \\
\text { to substances }\end{array}$} & Patient & $\begin{array}{l}\text { Extra information by physicians, friends, mental health experts, } \\
\text { family members, and discovers physical and chemical issues in the } \\
\text { assessment team (e.g., laboratory, imaging, specialist referrals). } \\
\text { Reveals further psychological and prior therapeutic issues; enables } \\
\text { coordination with other medical professionals or psychiatrists; } \\
\text { participating in evaluations; control of symptoms. }\end{array}$ \\
\hline & & PCP & $\begin{array}{l}\text { The key role of the present complaint submission in assessing likely } \\
\text { etiology. Carries out a full diagnostic differential and work diagnosis } \\
\text { of depression, inspection labs, tests, and health consultations if } \\
\text { necessary, and coordinates therapy with other health and mental } \\
\text { health experts. BHP coordinates for differential diagnosis. }\end{array}$ \\
\hline & & $\mathrm{BHP}$ & $\begin{array}{l}\text { Has a vital role to play in the registration and association of physical } \\
\text { symptoms with PCP to be evaluated. Consideration and co-screen- } \\
\text { ing and psycho-social evaluation; gathers further information; aids } \\
\text { PCPs by coordinating care with other physician providers; helps } \\
\text { clients to comply with medical advice. PC consultation to explain } \\
\text { diagnosis as necessary. }\end{array}$ \\
\hline & & $\mathrm{CP}$ & $\begin{array}{l}\text { Develop medical differentials if necessary; more testing is recom- } \\
\text { mended. Excludes differential diagnosis; makes a temporary } \\
\text { diagnosis. }\end{array}$ \\
\hline \multirow[t]{3}{*}{3.} & \multirow{3}{*}{$\begin{array}{l}\text { Medication: } \\
\text { Create an initial therapy plan that } \\
\text { is consistent with the patient's } \\
\text { treatment goals, and is suitable } \\
\text { for the biopsychosis of a unique } \\
\text { presentation. }\end{array}$} & Patient & $\begin{array}{l}\text { Participates actively in exploring therapy choices and developing an } \\
\text { initial treatment plan. Speaking about the treatment strategy, there } \\
\text { are voices. Following the initial advice on therapy, he discusses } \\
\text { challenges and concerns as treatment develops. }\end{array}$ \\
\hline & & PCP & $\begin{array}{l}\text { Establish and maintain a therapeutic alliance; inform patients about } \\
\text { the components of the treatment plan,; especially the use of drugs } \\
\text { and other medical treatments, Stresses the importance of address- } \\
\text { ing depression psychosocial players and other problems; such, as } \\
\text { chronic pain, and of closely collaborating with the BHP; identify and } \\
\text { assess medical treatment goals and monitor advancements. }\end{array}$ \\
\hline & & $\mathrm{BHP}$ & $\begin{array}{l}\text { Establishes and maintains a therapeutic alliance, focuses on crises } \\
\text { management and safety planning strategies, evaluates the full } \\
\text { treatment plan with the patient and addresses issues and issues, } \\
\text { provides brief actions to address co-morbid mental health and to } \\
\text { promote self-management of chronic pain (e.g., disability, vocational } \\
\text { rehab, social services, chemical dependency, additional psycho- } \\
\text { therapy). }\end{array}$ \\
\hline
\end{tabular}


Table 2 (continued)

\begin{tabular}{|c|c|c|c|}
\hline No. & Implementations & Components & Roles \\
\hline & & $\mathrm{CP}$ & $\begin{array}{l}\text { Resource for mental comorbidity diagnosis and treatment, informs } \\
\text { planning for treatments, supports the plan for safety, and advice for } \\
\text { medication and conduct management. }\end{array}$ \\
\hline \multirow[t]{4}{*}{4.} & \multirow{4}{*}{$\begin{array}{l}\text { Therapy monitoring and adjust- } \\
\text { ment to accomplish therapeutic } \\
\text { goals: } \\
\text { Monitoring progress, using stan- } \\
\text { dardized measuring tools every } \\
\text { two to four weeks (e.g., PHQ-9). }\end{array}$} & Patient & $\begin{array}{l}\text { Notify drug side effects treatment team or any treatment hurdles or } \\
\text { concerns, revises the CC team therapeutic strategy if required. }\end{array}$ \\
\hline & & PCP & $\begin{array}{l}\text { Retrains overall patient care duty. Adjusts the tolerance of psycho- } \\
\text { tropic medicine (i.e., managing side effects) or lack of efficacy when } \\
\text { required. Monitoring of medical or substance use contributions } \\
\text { conditions. }\end{array}$ \\
\hline & & $\mathrm{BHP}$ & $\begin{array}{l}\text { Provides behavior interventions, monitors the progress of patients' } \\
\text { therapy, adherence to treatments and psychosocial treatments, } \\
\text { facilitates communication between team members, continuing } \\
\text { needs assessment, and performing indicated references (disability, } \\
\text { vocational rehabilitation, social services, chemical dependence, and } \\
\text { additional psychosis). }\end{array}$ \\
\hline & & $\mathrm{CP}$ & $\begin{array}{l}\text { Regular psychiatric case reviews gives further suggestions for } \\
\text { modifications in treatment for patients who do not improve as } \\
\text { predicted, and for people who do not improve; despite the change } \\
\text { in treatment can carry out direct patient reviews (in person or by } \\
\text { telemedicine). }\end{array}$ \\
\hline \multirow[t]{4}{*}{5.} & \multirow{4}{*}{$\begin{array}{l}\text { Completing treatment and relapse } \\
\text { prevention: } \\
\text { The reciprocal preventive plan } \\
\text { should capture the patient's } \\
\text { important treatment measures. } \\
\text { This should involve beneficial } \\
\text { medical and psychological } \\
\text { techniques. }\end{array}$} & Patient & $\begin{array}{l}\text { Identification of early warning signals, routine monitoring of such } \\
\text { signs, family members, or other help, where possible. }\end{array}$ \\
\hline & & PCP & $\begin{array}{l}\text { Monitors the next stage of antidepressant treatment, and takes into } \\
\text { account the necessity for antidepressant maintenance management. } \\
\text { Considers long-term effects of medication. }\end{array}$ \\
\hline & & $\mathrm{BHP}$ & $\begin{array}{l}\text { Provides psychoeducation on depression recurrence. Assists patients } \\
\text { in building a reoccurrence prevention plan that identifies and } \\
\text { summarizes depression prevention measures, early warnings, and } \\
\text { actions to be taken when symptoms of depression get worse. } \\
\text { Monitor adherence to medications, behavioral activation measures, } \\
\text { and other approaches to prevent reoccurrence of depression. } \\
\text { Strengthen the application of patient behavioral policies. }\end{array}$ \\
\hline & & $\mathrm{CP}$ & $\begin{array}{l}\text { Assists in assessing maintenance management needs for antide- } \\
\text { pressants. BHP helps detect other lingering concerns; particularly for } \\
\text { mental health services, that have not yet been handled or forwarded. }\end{array}$ \\
\hline
\end{tabular}

PCP=Primary Care Provider, BHP=Behavioral Health Provider, PHQ-9=9-item Patient Health Questionnaire, CP=Consultant Psychiatry, $\mathrm{CC}=$ Collaborative Care 


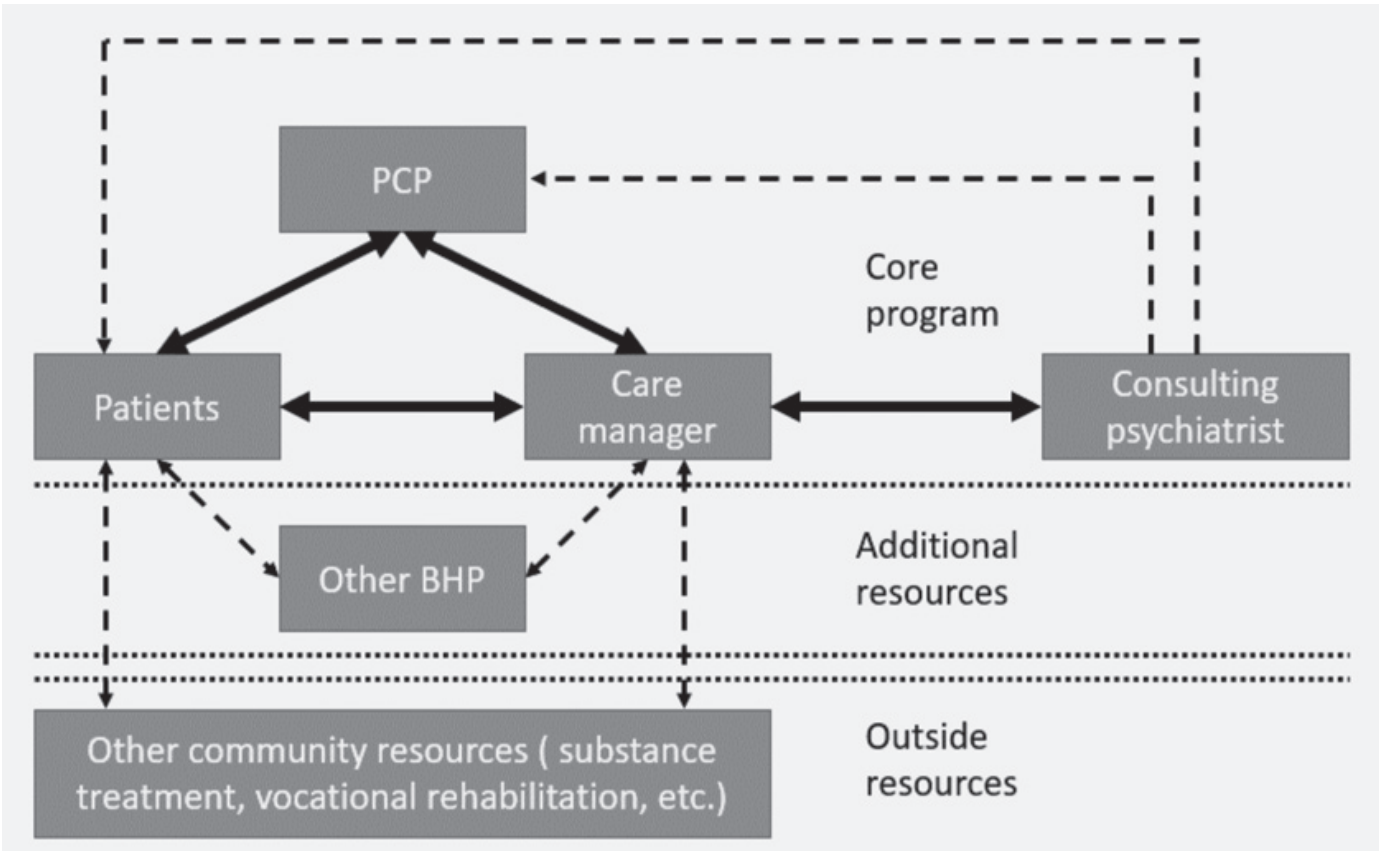

Figure 1 Interaction between collaborative care team members. ${ }^{1}$

stressed the need of including communities in long-term sustainability planning initiatives. ${ }^{30,31}$ Below are presented implementation barriers, which are categorized as: clinical barriers, organizational barriers, primary care physician practice orientation, and financial: $:^{25,31}$

\section{a. Clinical barriers}

Clinical hurdles include, the provider's failure to understand therapeutic directives and measuring-based care and distinguishing physical symptoms from moodrelated concerns. Communication focused on patients can eliminate the barriers, by better understanding of the patients' medical issues; thus, increasing the quality of treatment and results. Barriers to care at patient levels include: stigmatizing treatment attitudes and inadequate communication between patients and providers. ${ }^{31}$ Based on the study design for the use of collaboratory care in brittany et al. Community health centers, depression and anxiety treatment recommend that the initiation of CC is essential to receive proper training and preparation. In addition, one of the barriers to the implementation of this strategy is the shortage of resources within health services. ${ }^{32}$

\section{b. Organizational barriers}

Organizational obstacles to the implementation of collaborative care include: impediments to the delivery of care at the system level. Primary care organizations are only permitted to spend a limited amount of time on extensive assessments of mental health issues. The protection of historic privacy as well as the fear of an invasion of privacy have created hurdles to sharing information among primary and mental health professionals. This is further compounded by confusion over whom is accountable for treating a patient. Furthermmore, a lack of workers educated in evidencebased interventions leads to limited access to healthcare. ${ }^{33}$ This is exacerbated by the number of mental health workers whose proportions are not evenly distributed in all regions; especially in rural areas where there are almost no qualified health workers. This is a problem in almost all parts of the world. ${ }^{34}$ So, this makes it hard for primary 
healthcare workers to refer their patients if the need arises. The local government's role as policymakers; especially in health policies, can also contribute to the success of mental health. ${ }^{35-37}$

\section{c. Primary care physicians' practice patterns}

The third barrier is primary care practitioners behaviors, which considers the detection and treatment of depression to be the responsibility of mental health professionals, as part of their clinical practice or depressive medication. ${ }^{38}$ Unfortunately, in some countries, health workers that work in mental health primary services have multiple tasks in concern to their job, and do not focus on mental health services. ${ }^{36,39}$

\section{d. Financial}

The term "financial barrier", to implementing collaborative care" refers to finance and reimbursement concerns $^{25}$; wherein, there is a lack of funds to carry out screening for depression and collaborative management. Both depression screening and management maintenance involve the investment of additional costs, and there is no source of funds for this activity unless it is supported by research funds. ${ }^{25}$

\section{Conclusion}

$\mathrm{CC}$ is a holistic, multidisciplinary, and proactive treatment model to manage chronic diseases; in this case: depression. Depression is a mental disorder that is often lacking in detection and treatment in primary care settings. Effective treatment of depression, with the CC model, could therefore have major benefits; including, better clinical improvement, improved patient quality of life, and costeffectiveness.

\section{Acknowledgement}

The author is grateful to the Research and Innovation Institute, and Universitas Airlangga, who has helped in proofreading the manuscript and improvement of the English grammar.

\section{Funding source}

The authors have no funding to report.

\section{Conflict interest}

The authors have declared that no competing interests exist.

\section{References}

1. World Health Organization. Mental health in primary care: illusion or inclusion? [monograph on the Internet]. Geneva: WHO; 2018 [cited 2021 Apr 20]. Available from: https://apps.who.int/ iris/handle/10665/326298

2. Yeung A, Feldman G, Fava M. Care management of depression: treatment of depression in primary care and the need for a multidisciplinary approach. In: Duggal SH, editor. Selfmanagement of depression: a manual for mental health and primary care professionals. Cambridge: Cambridge University Press; 2009;p.24-45.

3. Ferenchick EK, Ramanuj P, Pincus HA. Depression in primary care: part 1-screening and diagnosis BMJ 2019;365:1794.

4. Ivbijaro GO, Enum Y, Khan AA, Lam SSK, Gabzdyl A. Collaborative care: models for treatment of patients with complex medical-psychiatric conditions. Curr Psychiatry Rep 2014;16: 506.

5. Ramanuj PP, Pincus HA. Collaborative care: enough of the why; what about the how? Br J Psychiatry 2019;215:573-6.

6. Ee C, Lake J, Firth J, Hargraves F, de Manincor M, Meade T, et al. An integrative collaborative care model for people with mental illness and physical comorbidities. Int $\mathrm{J}$ Ment Health Syst 2020;14:83.

7. Wagenaar BH, Petersen I, Rao D, Chwastiak L. 7 - Collaborative care models: a global perspective. In: Stein DJ, Bass JK, Hofmann SGBT, editors. Global mental health and psychotherapy: adapting psychotherapy for low- and middle-income Countries. London: Academic Press; 2019;p.153-70.

8. Eghaneyan BH, Sanchez K, Mitschke DB. Implementation of a collaborative care model for the treatment of depression and anxiety in a community health center: results from a qualitative case study. J Multidiscip Healthc 2014;7:503-13.

9. Sowa NA, Jeng P, Bauer AM, Cerimele JM, Unützer J, Bao Y, 
et al. Psychiatric case review and treatment intensification in collaborative care management for depression in primary care. Psychiatr Serv 2018;69:549-54.

10. Unützer J, Harbin H, Schoenbaum M, Druss BG. The collaborative care model: an approach for integrating physical and mental health care in medicaid health homes. Heal Home Inf Resour Cent [serial on the Internet]. 2013 [cited 2021 Apr 20];1-13. Available from: https://www.chcs.org/media/ HH_IRC_Collaborative_Care_Model_052113_2.pdf

11. Howick J. A qualified defence of the EBM stance on mechanistic reasoning. In: Howick J, editor. The philosophy of evidence-based medicine. Oxford: Wiley-Blackwell, Bmj; 2011;p.122-57.

12. Ratzliff $A$, Cerimele J, Katon W, Unützer J. Working as a team to provide collaborative care. In: Ratzliff A, Unutzer J, Katon $W$, Stephens KA, editors. Integrated care: creating effective mental and primary health care teams. Hoboken: John Wiley and Sons; 2016;p.1-24.

13. Kroenke K, Unutzer J. Closing the false divide: sustainable approaches to integrating mental health services into primary care. J Gen Intern Med 2017;32:404-10.

14. Dean J, Keshavan M. The neurobiology of depression: An integrated view. Asian J Psychiatr 2017;27:101-11.

15. Sadock BJ, Sadock VA, Ruiz P. Kaplan \& Sadock's synopsis of psychiatry: behavioral sciences/clinical psychiatry. $11^{\text {th }}$ ed. Philadelphia: Wolters Kluwer Health; 2014.

16. World Health Organization. Primary health care [homepage on the Internet]. Geneva: WHO; 2019 [cited 2021 Apr 20]. Available from: https://www.who.int/health-topics/primaryhealth-care\#tab=tab_1

17. Craven MA, Bland R. Depression in primary care: current and future challenges. Can J Psychiatry 2013;58:442-8.

18. Kementrian Kesehatan Republik Indonesia. Laporan Nasional RISKESDAS 2018. Badan Penelit dan Pengemb Kesehat [serial on the Internet]. 2019 [cited $2021 \mathrm{Apr}$ 20]; p.223-5. Available from: http://abdata.litbang.kemkes.go.id/images/ download/laporan/RKD/2018/Laporan_Nasional_RKD 2018_FINAL.pdf

19. Saldana L, Bennett I, Powers D, Vredevoogd M, Grover T, Schaper $\mathrm{H}$, et al. Scaling implementation of collaborative care for depression: adaptation of the stages of implementation completion (SIC). Adm Policy Ment Heal Ment Heal Serv Res 2020;47:188-96.
20. Goodrich DE, Kilbourne AM, Nord KM, Bauer MS. Mental health collaborative care and its role in primary care settings. Curr Psychiatry Rep 2013;15:383.

21. Jatchavala $C$, Chan S. Thai adolescent depression: recurrence prevention in practice. J Health Sci Med Res 2018;36:147-55.

22. Siu AL, Bibbins-Domingo K, Grossman DC, Baumann LC, Davidson $\mathrm{KW}$, Ebell $\mathrm{M}$, et al. Screening for depression in adults: US preventive services task force recommendation statement. JAMA 2016;315:380-7.

23. Purborini N, Lee MB, Devi HM, Chang HJ. Associated factors of depression among young adults in Indonesia: a populationbased longitudinal study. J Formos Med Assoc 2021;120: 1434-43.

24. Ying Yong X, Fai Sui C, Yee Liew M, San Chong TW, Young Liew J. Psychological distress screening for depression, anxiety and stress among medical ward patients in hospital Tapah, Malaysia: a cross-sectional study using the Depression, Anxiety and Stress Scale (DASS-21). J Health Sci Med Res 2021. doi: 10.31584/jhsmr.2021841.

25. Ellison JM. Integrated care in psychiatry: redefining the role of mental health professionals in the medical Setting. J Clin Psychiatry 2016;77:e172.

26. Raney LE. Integrating primary care and behavioral health: The role of the psychiatrist in the collaborative care model. Am J Psychiatry 2015;172:721-8.

27. Härter M, Watzke B, Daubmann A, Wegscheider K, König HH, Brettschneider $\mathrm{C}$, et al. Guideline-based stepped and collaborative care for patients with depression in a cluster-randomised trial. Sci Rep 2018;8:1-9.

28. Björkelund C, Svenningsson I, Hange D, Udo C, Petersson EL, Ariai $\mathrm{N}$, et al. Clinical effectiveness of care managers in collaborative care for patients with depression in Swedish primary health care: a pragmatic cluster randomized controlled trial. BMC Fam Pract 2018;19:28.

29. Atlantis E, Fahey P, Foster J. Collaborative care for comorbid depression and diabetes: a systematic review and metaanalysis. BMJ Open 2014;4:e004706.

30. Katon W, Unützer J. Collaborative care models for depression: time to move from evidence to practice. Arch Intern Med 2006;166:2304-6.

31. Sanchez K. Collaborative care in real-world settings: barriers and opportunities for sustainability. Patient Prefer Adherence 2017; $11: 71-4$. 
32. Eghaneyan BH, Sanchez K, Mitschke DB. Implementation of a collaborative care model for the treatment of depression and anxiety in a community health center: results from a qualitative case study. J Multidiscip Healthc 2014;7:503-13.

33. Overbeck G, Davidsen AS, Kousgaard MB. Enablers and barriers to implementing collaborative care for anxiety and depression: a systematic qualitative review. Implement Sci 2016;11:165.

34. Olfson M. Building the mental health workforce capacity needed to treat adults with serious mental illnesses. Health Aff 2016;35:983-90.

35. Rahvy A, Habsy A, Ridlo I. Actual challenges of mental health in Indonesia: urgency, UHS, humanity, and government commitment. Eur J Public Health 2020;30:2018-20.

36. Idaiani S, Riyadi El. Sistem Kesehatan Jiwa di Indonesia: tantangan untuk memenuhi kebutuhan mental health system in Indonesia: a challenge to meet the needs. J Penelit dan Pengemb Pelayanan Kesehat 2018;2:70-80.
37. Mahendradhata Y, Trisnantoro L, Listyadewi S, Soewondo P, Marthias T, Harimurti P, et al. The Republic of Indonesia Health System Review, Health System in Transition [monograph on the Internet]. New Delhi: WHO Regional Office for South-East Asia; 2017 [cited 2021 Apr 20]. Available from: https://apps. who.int/iris/handle/10665/254716

38. Rugkåsa J, Tveit OG, Berteig J, Hussain A, Ruud T. Collaborative care for mental health: a qualitative study of the experiences of patients and health professionals. BMC Health Serv Res 2020;20:1-10.

39. Hoeft TJ, Fortney JC, Patel V, Unützer J. Task-sharing approaches to improve mental health care in rural and other low-resource settings: a systematic review. J Rural Health 2018;34:48-62 